原著

\author{
特定地区のメニエール病確実例有病率調査 \\ 將積日出夫 ${ }^{1)} \cdot$ 渡辺 行雄 $^{1)} \cdot$ 赤荻 勝一1)

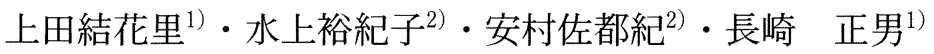

\title{
Prevalence of Definite Cases of Meniere's Disease in Niigata Prefecture
}

\author{
Hideo Shojaku ${ }^{1)}$, Yukio Watanabe ${ }^{1)}$, Katsuichi Akaogi ${ }^{1)}$, \\ Yukari Ueda ${ }^{1)}$, Yukiko Mizukami ${ }^{2}$, Satsuki Yasumura ${ }^{2)}$, Masao Nagasaki ${ }^{1)}$ \\ 1) Department of Otolaryngology, Toyama Medical and Pharmaceutical University \\ 2) Department of Otolaryngology, Itoigawa General Hospital
}

\begin{abstract}
Prevalence of definite cases of Meniere's disease (M.D.) in Nishikubiki district, the western part of Niigata prefecture, was investigated. All of the hospitals and clinics were surveyed between Jan. 1 and Dec. 31, 1994. Definite cases of M.D. was defind by the criteria proposed by the Meniere's Disease Research Committe of Japan. There were 13 definite cases (12 cases reported from ENT clinics and 1 case from a general practice). Surveying all ENT clinics was quite useful for evaluating the prevalence of definite cases of M.D. in a restricted area. Prevalence was 23 per 100000.
\end{abstract}

Key words: Meniere's disease, definite case, prevalence, database, Niigata Prefecture

\section{はじめに}

メニエール病 (メ病) の有病率調查は, これま で主に全診療科を対象とした調查が行われた 1) 4) が，回収率の低下や診断の信頼性5)6) が大き な問題であった。そこで私共は，メニエール病 （又病）確実例有病率調査方法として耳鼻咽喉科 全数調査法 (医薬大試案) を提案, 新潟県西頸城 地区7), 富山県東部地区, 岐阜県飛驒地区 ${ }^{8)}$ に拉 いて有病率を報告してきた。今回は新潟県西頸城 地区で耳鼻咽喉科以外の全医療機関を対象として 人病確実例患者数を調査することで有病率調査に 扣ける医薬大試案の有用性を検討した。

対象亡方法

平成 6 年 1 月 1 日から 12 月 31 日末でに, 新潟県

富山医科薬科大学耳鼻咽喉科学教室

2) 系魚川総合病院耳鼻咽喉科
西頸城地区に唯一耳鼻咽喉科を開設する地域の中 核的総合病院を通じて, 耳鼻咽喉科以外の全医療 機関を受診したメ病確実例を調査した。西頸城地 区は新潟県西部に位置しており, 東から名立町, 能生町, 系魚川市, 青海町の 4 市町より成り立つ 人口約 6 万人の漁業と農業が主体の臨海地域であ る。このうち名立町については, 多数の耳鼻咽喉 科診療施設の存在する上越市に接しており, 同地 区の生活圏や患者の系魚川総合病院への受診状況 から見て上越市内の耳鼻咽喉科への受診傾向が強 いと判断したため, 有病数調査の対象から外し た。そのため, 対象地区は 1 市 2 町で総人口は 5 万 6 千人となった。また医療機関の内訳は, 病院 3 (いずれも耳鼻咽喉科開設せず), 内科開業医 22 , 外科開業医 1 , 整形外科開業医 1 , 産婦人科 開業医 1 であり計28施設であった。

入病確実例の判定は厚生省メニエール病調査研 
究班の判定基準に従い, 調査は 3 段階に分けて行 った。まず第 1 次調査では, 調査対象全医療機関 に個人調査票を配布し, 保険病名がメ病またはメ ニエール症候群であった症例の臨床症状の記入を 依頼した。1 次個人調查票 ${ }^{1)}$ の質問項目は, 施設 名, カルテ番号, 患者氏名, 性別, 生年月日, 現 住所, 患側, めまい, 蝸牛症状, 嘔気・嘔吐, 意 識障害, 複視の12項目であった。1 次調査票から (1)めまい発作が 2 回以上で, (2)めまい性状が回転 性の久もしくは回転性・非回転性混合のいずれか であり，(3)少なくとも難聴，耳鳴のいずれか一方 がめまいに随伴していること全てが確認された場 合にのみ 2 次調査対象例と判定した。1 次調査個 人票では，回収率を上げるために簡単に記入する ことに留意して, めまいに難聴・耳鳴のいずれか が随伴するかどらかのみを質問した。この場合， めまい発作以前から存在していた蝸牛症状につい ても随伴症状と回答してきた可能性も否定できな かった。そのため 2 次調査個人調査票（図 1 ）を 作成し, 調査対象例の加療中の医療機関に配布し た。結果から，めまい発作に随伴して難聴と耳鳴 の少なくともいずれか一方の増悪, 緩解を確認す ることができた場合に，3 次調査対象例と判定し た。3 次調査では，まず各医療機関の主治医に対 して患者に糸魚川総合病院耳鼻咽喉科を受診させ ることを依頼した。系魚川総合病院耳鼻咽喉科を 受診した患者に対しては, 問診, 視診, 純音聴力 検査を行って, 最終的にメ病確実例の判定を行っ た。

\section{結果}

回収率（表 1 ）は，1 次調査では個人調査票は 28 施設中 28 施設から回収もしくは該当者がない場 合はその旨の回答を得ることができ, 回収率は 100\%であった。2 次調査では, 1 次調査で判定さ

\footnotetext{
（1）難聴 (耳鳴) の程度はめまいに一致して 変化しましたか? ｜はい・いいえ・不明 はいと答えた場合

(2) 難聴 (耳鳴) の程度はめまいがおこると 悪くなった? （はい・いいえ・不明 はいと答えた場合

（3）難聴 (耳鳴）の程度はめまいが良くなると 良くなった? 梳・いいえ・不明
}

図 12 次調査個人調查票
れた 6 施設 29 症例に対して個人調査票を配布し て，6 施設中全てから回答を得ることができ，回 収率は $100 \%$ であった。

1 次調査により93症例がメ病またはメニエール 症候群として耳鼻咽喉科以外の28医療機関に受診 していたことが明らかとなった（表 2 ）。そのら ち，29例（31\%）が先の条件を充たしてメ病確実 例が疑われる症例と判定された。2次調査により 条件を充たしてメ病確実例が疑われた症例は 29 症 例中 7 症例 $(24 \%)$ であった。

3 次調查では, 2 次調査で判定された 3 施設 7 症例のうち 5 症例に捛いて糸魚川総合病院耳鼻咽 喉科で問診, 視診, 純音聴力検査を受けることが できた。その結果 1 症例は, 入病確実例と判定さ れた。この症例は, 平成元年から 3 年まで糸魚川 総合病院耳鼻咽喉科でメ病確実例の診断で治療を 受けており，4年から近医で治療の継続を受けて いた。残り 4 症例はメ病確実例ではなかった。な 特レ線検査を含む神経耳科学的検査は患者の協力 が得られず行えなかった。7 症例中残りの 2 症例 は, 他院入院中により系魚川総合病院を受診でき ず， 3 次調査で判定できないドロップアウト症例 となった。

\section{考察}

これまで私共は, 久病確実例の有病率推定法と して医薬大試案を考案, 実態調査に利用してき た8)。これは, メ病ではめまい並びに蝸牛症状を

表 1 調查毎の回収率の比較

\begin{tabular}{lrrr}
\hline & 配布施設 & 回収施設 & 回収率 \\
\hline 1次調査 & 28 & 28 & 100 \\
2次調查 & 6 & 6 & 100 \\
\hline
\end{tabular}

表 2 個人調查票に基づくメ病判定結果

\begin{tabular}{lcc}
\hline & 回収調査票 & メ病判定例 \\
\hline 1次調査 & 93 & 29 \\
2次調査 & 29 & 7 \\
\hline
\end{tabular}


主訴とするために耳鼻咽喉科を必ず一度は受診す るといら仮説に従い，対象地区の耳鼻咽喉科受診 患者中の確実例を調査してデータベースを作成, 対象地区の人口から人口 10 万人対の有病率を計算 するものである。この方法により, 新潟県西頸城 地区に拈いて平成 6 年 1 月 1 日から 12 月 31 日まで のメ病確実例は12例であることを既に報告してき た。今回の研究では, 同一地区, 同一期間で耳鼻 咽喉科以外の全医療機関（28施設）を対象として

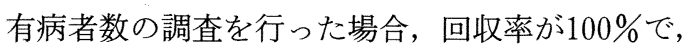
メ病確実例と判定されたのはわずかに 1 例であっ た。つまり耳鼻咽喉科以外調査のメ病確実例は 13 例中 1 例であり, 特定地区のわずかに $8 \%$ であっ た。全国の 200 床以上の総合病院ではメ病確実例 の $98 \%$ が耳鼻咽喉科患者であったといら報告5) と 同様に, メ病確実例の疫学調査方法として全耳鼻 咽喉科調查（医薬大試案）の有用性は高いことが 示唆された。さらに今回の研究に拈いて, 耳鼻咽 喉科以外の医療機関調査によりデータベースに登 録された 1 症例は, 過去に同地区内耳鼻咽喉科を 受診した治療歴を持っていることが明らかとなっ た。したがって, 全耳鼻咽喉科多年度調査により 対象地区の正確な確実例の患者数の把握が可能と なることが推察された。

疫学調査では, 常に回収率が問題となってき た。そこで今回の調査では, 個人調査票作成時に 質問項目数を最低限度とする, 必要以外は記入事 項をなくするなどの工夫を行い，回収率の向上を 図った。さらに，西頸城地区医師会のバックアッ プを得ることができたことと，めまい治療で現在 でも同地区で中核的な役割を果たしている総合病 院を通じて疫学調査を行ったため, 各医療機関で の協力が得やすく, 調查がスムーズに運んだこと などが 1 次・ 2 次調査での $100 \%$ の回収率につな がったと考兄られる。規模は小さいが西頸城地区 の疫学調査は, 各種疫学的指標の推計に極めて有 益であると思われた。

厚生省メニエール病調査研究班の判定基準9) は 問診からメ病確実例, 疑い例の診断が可能なた め, これまでの疫学調査に広く用いられてきた。 今回の調査でも, 判定基準に従い 2 段階の個人調 查票の質問項目を設定した。1 次調査でメ病確実 例が疑われた大多数（29症例中 22 症例）が 2 次調 査でメ病確実例から除外されたことは，ただ単に
蝸牛症状がめまいに随伴しているかどうかを単純 に質問しただけでは不十分であり，2 次調査のよ らに蝸牛症状がめまいに伴って増悪, 緩解を示し たかを質問項目に入れる必要があると考えられ た。この点を今後の疫学調査に括ける個人調査票 の作成時に留意する必要がある。

最後に, 今回の研究では 3 次調査として耳鼻咽 喉科専門医の診察と純音聴力検查を実施した。厚 生省メニエール病調査研究班の判定基準9)では, 入病確実例診断に検査は必ずしも必要ではない。 しかしながら，中耳炎などによる反復性めまい発 作を除外7)するためには，耳鼻咽喉科医の視診や 聴力検査による気導骨導聴力差の有無の確認が最 低限必要となる。1995年に AAO-HNS から出さ れた新しいメニエール病診断基準10)に扣いても, definite Meniere's disease の診断には 1 回以上の 聴力検査の実施が必須事項と明記されている。め まい専門病院以外の医療機関を対象とした疫学調 査の場合, 内リンパ水腫推定検査等を行う ${ }^{11)} こ$ とは事実上不可能であるが, メ病確実例の有病率 調査の正確性を増すためには, 耳鼻咽喉科以外調 査では最終段階で聴力検査を含めた耳鼻咽喉科受 診を可能な限り実施すべきであると考えた。

\section{結 論}

新潟県西頸城地区を対象とした耳鼻咽喉科以外 の全医療機関調查方法より調査されたメニエール 病確実例は耳鼻咽喉科調査に比べごく少数であ り, 確実例の疫学調查には全耳鼻咽喉科調査が極 めて有用であると考兄られた。

\section{謝 辞}

研究にあたりご協力をいただきました糸魚川 市, 西頸城郡医師会会員の皆様に心から感謝いた します。

本研究は, 厚生省前庭機能異常調査研究班の研 究助成により行われた。

\section{文献}

1 ) 中江公裕, 新田裕史, 服部芳明甫, 他: メ二 エール病の有病率.耳鼻臨床 $73: 1023-1029$, 1980

2 ) 橋本 勉, 笠松隆洋, 北浦清剛, 他 : メ二 エール病全国調査の解析一第一次調査, 第二 次調査からの患者数の推計と性, 年齢別分布 —. Equilibrium Res Suppl 5: 22-25, 1989 
3 ）水越鉄理, 將積日出夫, 浅井正嗣, 他: 富山 県に括けるメニエール病患者の疫学調査.耳 鼻臨床 76:2215-2220, 1983

4 ) 岡本幹三, 森尾眞介, 瀧田親友朗, 他 : メ二 エール病全国患者数の推計一地方自治体実施 の全医療機関患者調査よりの推計一. Equilibrium Res Suppl 9: 1-4, 1993

5 ) 新関泰夫, 渡辺 勈, 水越鉄理, 他 : 入二 エール病全国調査の解析 (続報). Equilibrium Res Suppl 6: 1-10, 1990

6 ) 渡辺行雄, 將積日出夫, 神田憲一, 他 : 県医 師会調査および当科受診症例による富山県の メニエール病疫学調査結果. Equilibrium Res Suppl 8: 4-8, 1992

7 ) 將積日出夫, 渡辺行雄, 伊東宗治, 他: メ二 エール病確実例の有病率調査に関する研究— 新潟県西頸城地区での調査一. Equilibrium Res 55: 314-320, 1996

8 ）赤荻勝一, 將積日出夫, 長崎正男, 他 : メ二
エール病確実例疫学調査一岐阜県飛驒地区と 富山県東部地区に扣ける調査一. Equilibrium Res 57: 49-53, 1998

9 ) 渡辺 勈: 厚生省研究班のメニエール病診断 基準について.耳鼻臨床 69: 301-303, 1976

10) Committee on Hearing and Equilibrium: Committee on Hearing and Equilibrium guideline for the diagnosis and evaluation of therapy in Meniere's disease. Otolaryngol Head Neck Surg 113: 181-185, 1995

11）小松崎篤, 二木 隆, 原田康夫, 他：めまい の診断基準化のための資料一1987年めまいの 診断基準化委員会一. Equilibrium Res 47: 247-248, 1988

$\left(\begin{array}{l}\text { 原稿到着 : 平成 } 10 \text { 年 } 2 \text { 月 } 20 \text { 日 } \\ \text { 別刷請求先 : 將積日出夫 } \\ \text { 干930-0194 富山市杉谷 } 2630 \\ \text { 富山医科薬科大学耳鼻咽喉科学教室 }\end{array}\right)$

